CATALLAXY

Volume 3 Issue 2 December 2018

e-ISSN 2544-090X

C www.catallaxy.pl

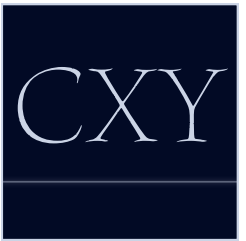

Oryginalny artykuł naukowy

otrzymano: 07.05.2018 / zaakceptowano: 25.06.2018 / opublikowano online: 30.06 .2018

Pałgan, K. (2018). Indie w globalnym systemie pomocy rozwojowej. Catallaxy, 3(2): 81-88. doi:10.24136/cxy.2018.009.

\title{
Indie w globalnym systemie pomocy rozwojowej
}

\author{
KATARZYNA PAEGAN \\ Uniwersytet Ekonomiczny w Poznaniu, al. Niepodległości 10, 61-875, Poznań, Polska \\ \katarzyna.palgan1210@gmail.com \\ (D) orcid.org/0000-0002-7503-4286
}

\begin{abstract}
Abstrakt
Motywacja: W literaturze przedmiotu brakuje oceny efektywności pomocy rozwojowej otrzymywanej i świadczonej przez Indie. Korzyści wynikające z uzupełnienia istniejącej luki poznawczej były głównym motywem podjęcia tematu. Cel: Celem artykułu jest ocena pomocy rozwojowej, kierowanej do Indii, jako jednego z wschodzących donatorów. Uwzględniono różne aspekty rozwoju, zwłaszcza w perspektywie najmniej zamożnych mieszkańców państwa.

Materiały i metody: Wykorzystano analizę literatury przedmiotu, analizę danych wtórnych, obserwację uczestniczącą oraz analizę wizualną.

Wyniki: Na podstawie przeglądu literatury oraz wniosków z obserwacji można wyciągnąć wniosek o braku skuteczności oraz efektywności pomocy rozwojowej zarówno otrzymywanej, jak i świadczonej przez Indie. Ponadto stwierdzono, że przypadek Indii wskazuje na niezgodność definicji pomocy rozwojowej jako instrumentu prowadzącego do rozwoju państw-beneficjentów, a raczej jako środka tworzenia relacji politycznych i ekonomicznych służących w głównej mierze państwom donatorom.
\end{abstract}

Stowa kluczowe: pomoc rozwojowa; Indie; wschodzacy donatorzy

JEL: 131;019; N45

\section{Wprowadzenie}

Obecnie, pomoc rozwojowa dotyczy większości państw świata. Poza wsparciem płynącym $z$ poszczególnych państw, $w$ jej administrowanie i finansowanie włączają się także organizacje o charakterze multilateralnym (wielostronnym) takie, jak Bank Światowy, czy Organizacja Narodów Zjednoczonych (ONZ) oraz niezwykle liczna grupa organizacji pozarządowych (Kopiński, 2011, s. 7). Zarówno pojęcie pomocy rozwojowej, jak i samego rozwoju, stwarza wiele problemów już na poziomie definiowania, a co za tym idzie, także interpretacji. Skutkuje to komplikacją w mierzeniu skuteczności i efektywności przekazy- wanego wsparcia. Motywy udzielania pomocy rozwojowej sprawiają, że wśród dotychczasowych państw-biorców coraz częściej pojawia się inicjatywa bycia donatorem. Powstaje pytanie o to, dlaczego społeczeństwa, które borykają się z wieloma problemami wynikającymi $z$ niedoboru zasobów, gotowe są nieść pomoc innym potrzebującym.

Niniejszy artykuł oparto na przypadku Indii, które należą do grupy wschodzących donatorów pomocy rozwojowej. Dzięki analizie danych oraz obserwacji przeprowadzonej w stanie Orisa w Indiach, nakreślono sytuację ekonomiczną, polityczną oraz społeczną Indii $\mathrm{w}$ kontekście pomocy rozwojowej, zarówno otrzymywanej, jak i świadczonej przez 
to państwo. Celem pracy jest ocena tej pomocy $w$ kontekście roli, jaką, zgodnie z definicją, powinna pełnić.

W sekcji 2. przedstawiono definicje pojęć pomocy rozwojowej oraz rozwoju oraz scharakteryzowano rodzaje przekazywanego wsparcia. Następnie krótko omówiono przypadek Indii, zarówno jako wschodzącego donatora, jak i beneficjenta pomocy rozwojowej. Wskazano istotne aspekty historyczne, polityczne i ekonomiczne, których efektem jest obecna sytuacja Indii, zarówno na arenie międzynarodowej, jak i w perspektywie regionalnej i lokalnej państwa. W sekcji 3. zaprezentowano zastosowane metody badawcze. W sekcji 4. zawarto wyniki z przeprowadzonej analizy, natomiast $w$ sekcji 5 . podsumowano omawiane zagadnienia.

\section{Przegląd literatury}

\subsection{Definicja pomocy rozwojowej i rozwoju}

W literaturze przedmiotu istnieje wiele różnych definicji pomocy rozwojowej. Według OECD (2018), oficjalna pomoc rozwojowa (official development assistance, ODA) to „darowizny i pożyczki przekazane państwom rozwijającym się przez oficjalne instytucje rządowe państw bogatych lub organizacje międzynarodowe mające na celu wsparcie rozwoju gospodarczego i dobrobytu w tych państwach". Natomiast zgodnie $z$ definicją $O N Z$, jest to „pomoc świadczona przez państwa oraz organizacje międzynarodowe $\mathrm{w}$ formie finansowej, materialnej czy doradczej na rzecz państw mniej rozwiniętych. Celem pomocy rozwojowej jest redukcja ubóstwa, promocja zrównoważonego rozwoju, wsparcie reform demokratycznych i rządów prawa, przestrzeganie praw człowieka, rozwój społeczeństwa obywatelskiego, wspieranie wzrostu gospodarczego, zapobieganie konfliktom oraz promocja bezpieczeństwa globalnego" (Kopiński, 2011, s. 15). Obszerność definicji może rodzić wątpliwości, przykładowo przy ocenie sku- teczności pomocy. Samo wsparcie praworządności i reform demokratycznych nie wiąże się $z$ poprawą jakości życia obywateli w państwie, które otrzymuje pomoc. Również wsparcie finansowe i techniczne może obyć się z wyłączeniem o dbałość w aspekcie demokratyzacji i praw człowieka. Przykładem są Chiny lub wiele państw Afrykańskich (Kopiński, 2011, ss. 13-15).

W niniejszym artykule ODA nie jest równoznaczna $z$ pojęciem pomocy rozwojowej. Zawarto także opis pomocy gospodarczej, która, według definicji, nie jest zaliczana do ODA.

Pojęcie rozwoju również nie jest jednoznaczne. Zgodnie ze Słownikiem Języka Polskiego PWN (2018), rozwój jest to „proces przechodzenia do stanów lub form bardziej złożonych lub pod pewnym względem doskonalszych". Rozwój gospodarczy, czy też ekonomiczny, rozumiany jest jako ,jakościowe i strukturalne zmiany w gospodarkach będące następstwem wzrostu gospodarczego" (Encyklopedia PWN, 2018). Szerszą definicją jest promowane, zwłaszcza w ostatnich latach $\mathrm{w}$ kontekście różnych strategii rozwoju, pojęcie rozwoju zrównoważonego. Według Encyklopedii PWN (2018), jest to „rozwój trwały, termin oznaczający rozwój społeczno-ekonomiczny współczesnych społeczeństw polegający na zaspokajaniu ich potrzeb $w$ taki sposób, aby nie zmniejszać możliwości zaspokajania potrzeb przyszłym pokoleniom". Natomiast rozwój społeczny określany jest jako „potocznie całokształt zmian, jakim ulega dane społeczeństwo (lub nawet społeczeństwo ludzkie w ogólności)" (Encyklopedia PWN, 2018).

Analizując rozwój należy mieć na uwadze jego trzy aspekty: gospodarczy, polityczny i społeczny. Aspekty te przenikają się, wpływając na siebie wzajemnie. W przypadku rozwoju, poprawa w zakresie jednego $z$ aspektów, niekoniecznie niesie poprawę $w$ innym, a niekiedy nawet wiąże się z pogorszeniem sytuacji $w$ innej dziedzinie, co powoduje trudności w badaniach nad rozwojem. 


\subsection{Rodzaje pomocy rozwojowej}

Z uwagi na różnie kryteria można wyróżnić kilka rodzajów i form pomocy rozwojowej. Ze względu na źródło pochodzenia pomoc rozwojową można podzielić na (Kopiński, 2011, ss. 19-23):

- bilateralną (dwustronną, przekazywaną od rządów państw-dawców do państw-biorców);

- multilateralną (wielostronną, przekazywaną za pośrednictwem wyspecjalizowanych instytucji międzynarodowych);

- prywatną (niezaliczaną do ODA, składającą się z datków charytatywnych, przekazów osób prywatnych oraz organizacji pozarządowych).

Ze względu na kryterium formy przekazywania, można wyróżnić pomoc:

- finansową (transfery pieniężne);

- rzeczową (pomoc w naturze, np. żywność, leki, sprzęt);

- techniczną (transfer wiedzy i know-how, np. usługi doradcze, konsultingowe, szkolenia).

Ze względu na stopień swobody wykorzystania, można wyróżnić pomoc:

- niewiązaną;

- wiązaną (wydatkując środki na rozwój, państwo-beneficjent musi przeznaczyć je na towary lub usługi oferowane $w$ państwie-dawcy); $z$ uwagi na ograniczoną efektywność tego rozwiązania celem państw rozwiniętych jest rezygnacja $z$ tego rodzaju pomocy.

Ze względu na kolejne kryterium, jakim jest przeznaczenie, pomoc można podzielić na:

- projektową (środki, głównie finansowe, przeznaczane są na wykonanie określonych szczegółowo $\mathrm{w}$ czasie i przestrzeni działań o łatwo mierzalnych efektach);

- programową (wsparcie państwa-biorcy na rzecz wewnętrznych reform gospodarczych, jej efekty mają charakter niematerialny, trudno je zmierzyć).

Istotną kategorią pomocy jest pomoc humanitarna dotycząca ratowania oraz ochrony życia podczas klęsk i katastrof żywiołowych lub będących efektem działania człowieka (np. wojen lub ataków terrorystycznych). Pomoc humanitarna jest zaliczana do ODA tylko w szczególnych przypadkach - kiedy ma ona trwały, długofalowy charakter, a nie stanowi jednorazowego, doraźnego wsparcia.

\subsection{Pomoc rozwojowa w Indiach}

Indie należą do grupy wschodzących donatorów. Są ciekawym przypadkiem państwa, które nie tylko otrzymuje pomoc, ale sam także ją świadczy. W indyjskiej historii gospodarczej wyróżnić można trzy etapy rozwoju systemu pomocy zagranicznej:

- pomoc w okresie zimnowojennym (1947-1991);

- pomoc w okresie przejściowym (1992-2002);

- współczesny system pomocowy (od 2003 roku).

W 1947 roku Indie odzyskały niepodległość i wkrótce po tym wydarzeniu rozpoczęły świadczenie zagranicznej pomocy gospodarczej. Stworzono liczne programy pomocowe, które obejmowały państwa rozwijające się $w$ Azji, Afryce oraz w mniejszym stopniu w Ameryce Południowej. Była to pomoc finansowa, świadczona $\mathrm{w}$ niewielkim zakresie ze względu na sytuację gospodarczą (obejmowała Nepal, Bhutan, Sri Lankę, Afganistan, Malediwy). Indie oferowały $\mathrm{w}$ tym czasie głównie pomoc techniczną, ze względu na wysokie wykształcenie urzędników będące skutkiem kolonializmu.

Kryzys gospodarczy w Indiach spowodował znaczne zmniejszenie środków na pomoc rozwojową i zapoczątkował okres przejściowy. Reformy restrukturyzujące i liberalizujące gospodarkę indyjską, wprowadzone przez nowe władze, spowodowały gwałtowny wzrost gospodarczy państwa. W tej sytuacji państwo znowu mogło podjąć się działań pomocowych.

Współczesny, indyjski system pomocowy opiera się na trzech filarach (Nowik, 2014, ss. 689-693):

- granty i pożyczki preferencyjne,

- program pomocy technicznej,

- preferencyjne linie kredytowe. 
Pomoc rozwojowa, świadczona przez Indie nie jest podyktowana jedynie poczuciem solidarności $z$ innymi państwami rozwijającymi się, ale także dumą Indii jako państwa, które chce zaznaczyć swój ślad na kartach historii świata. Po pierwsze, należy podkreślić, że pomoc, jaką świadczy Indyjskie Ministerstwo Spraw Zagranicznych $\mathrm{i}$ inne, państwowe instytucje, nie jest w pełni zgodna $z$ kategoriami ODA i definicją OECD (2018). Należałoby wykluczyć, np. oferowaną pomoc militarną. Również program linii kredytowych, definiowany jako program pomocowy, nastręcza wątpliwości poprzez fakt, że uzyskane przez biorcę środki, mogą być wydatkowane wyłącznie na zakup indyjskich produktów i usług (Nowik, 2014, s. 692). Świadczenie pomocy rozwojowej przez Indie ma służyć nie tylko państwom beneficjentom, ale także donatorowi.

Można wyróżnić trzy motywy udzielania pomocy: ekonomiczny, polityczny i humanitarny. Pomoc ekonomiczna, świadczona przez Indie ma głównie charakter pomocy wiązanej wspierającej rozwój ekonomiczny państwa.

$\mathrm{W}$ aspekcie politycznym, pomoc jest narzędziem zapewnienia bezpieczeństwa międzynarodowego i narodowego, ale także regionalnego. Według badań przeprowadzonych przez A. Alesina i D. Dollar (1998), pomoc udzielana jest sojusznikom politycznym i państwom podejmującym podobne decyzje polityczne (np. podczas głosowań na zgromadzeniu ONZ). Jest to też wyraz zaistnienia na arenie międzynarodowej, jako hojnego, ale także silnego państwa, które może równać się $z$ innymi donatorami, gdyż samo jest donatorem.

Do motywów humanitarnych należy moralny obowiązek, jaki rodzi się z dysonansu kognitywnego (napięcie powstające wskutek uświadomienia sobie, że w danym systemie poznawczym istnieją dwa sprzeczne elementy). Indie, jako państwo, które doświadczyło wielu kryzysów gospodarczych, a także ucisku kolonialnego, pragną wesprzeć inne państwa, które tej pomocy potrzebują. Jednak, analiza struktury świadczonej pomocy, np. wsparcia militarnego czy wysokiego poziomu pomocy wiązanej, wskazuje, że motyw humanitarny raczej nie jest głównym czynnikiem, którym kierują się indyjskie władze (Kopiński, 2011, ss. 25-38).

Indie są także beneficjentem pomocy rozwojowej. Zgodnie $z$ danymi OECD (2018), należą one do państw niższym, średnim dochodzie. Ważnymi partnerami są tutaj: Wielka Brytania, Japonia, Unia Europejska (UE). Stosunki te są podyktowane różnymi czynnikami, głównie polityczno-ekonomicznymi. Indie były niegdyś brytyjską kolonią, dlatego Wielka Brytania oferuje swoją pomoc, aby naprawić negatywne stosunki, które mogą wynikać z tego historycznego okresu. Indie należą do największych i najszybciej rozwijających się państw na świecie. Nominalny PKB Indii wynosi 2 bln USD. Jest to trzecia najwyższa wartość tego wskaźnika w Azji - po Chinach i Japonii (Szulec, 2015). Ekonomiści z brytyjskiego Centrum ds. Badań Ekonomicznych i Biznesowych (Centre for Economics and Business Research, CEBR, 2014), uważają, że jeśli w ciągu kilkunastu najbliższych lat Indie utrzymają takie tempo rozwoju, to mają szansę wyprzedzić w tym zakresie nie tylko Japonię, ale nawet kilka państw UE i zostać trzecią potęgą gospodarczą świata. Nic więc dziwnego, że tak wielu państwom zależy na dobrych stosunkach $z$ Indiami, zarówno gospodarczych, jak i politycznych.

W rzeczywistości Indie borykają się z wieloma trudnościami. Zarządzanie tak wielkim państwem nie jest łatwe. Podział administracyjny, wielość języków, kultura i styl bycia Hindusów sprawiają, że państwo zmaga się $z$ wieloma problemami. Na poziomie makroekonomicznym można wyróżnić następujące: wysoka stopa inflacji, deficyt handlu zagranicznego, zbędna biurokratyzacja, niewłaściwe zarządzanie będące źródłem paradoksów i nieporozumień, bariery wejścia dla zagranicznych inwestorów, ubóstwo. Problemy te dostrzegalne są zwłaszcza na poziomie lokalnym. Większość obywateli nie ma wsparcia od administracji, głównie przez problem korupcji oraz funkcjonujący nadal system kastowy. 


\subsection{Pomoc rozwojowa dla stanu Orisa}

Orisa jest jednym ze stanów położonych w południowo-wschodnich Indiach, nad Zatoką Bengalską, o powierzchni $155707 \mathrm{~km}^{2}$. Żyje tam około 43,73 mln osób. Stan Orisa ma wysoką bazę zasobów naturalnych, ogromny pas nadmorski, wysokie pokrywy leśne i znaczne rezerwy minerałów, a także dobre i żyzne gleby. Jednak wśród całej tej obfitości, region ten uznano za jeden $z$ najbardziej zacofanych w Indiach (World Bank, 2016, s. 1). Stan jest słabo zurbanizowany. Według ostatniego spisu powszechnego z 2011 roku, 83\% ludności mieszkało na obszarach wiejskich. Około $40 \%$ ludności stanu stanowi najniższa kasta oraz jeszcze niższe w hierarchii społecznej plemiona. Głównym zajęciem ludności wiejskiej jest rolnictwo. Podstawowym źródłem utrzymania $60 \%$ ludności wiejskiej stanu jest rolnictwo. Sektor przemysłowy jest głównie zdominowany przez działalność wydobywczą (Sahoo, 2015, s. 4). W 2014 roku PKB per capita wynosił 24928 INR (niecałe 1330 PLN), podczas, gdy średnia krajowa wyniosła $w$ tym czasie 39904 INR. 90\% całkowitej liczby ubogich $\mathrm{w}$ stanie pochodzi z obszarów wiejskich. Mimo, że od 1993 roku liczba ubogich w stanie Orisa spadła o około połowę, to i tak stanowi obecnie ponad 30\% ludności (Sahoo, 2015, s. 8). Jednym z głównych celów pomocy rozwojowej jest redukcja ubóstwa. Na przestrzeni lat partnerzy Indii niejednokrotnie wspierali w różnych obszarach ten region. W 1997 roku Bank Światowy przekazał środki finansowe dla stanu Orisa w celu realizacji projektu na rzecz rozwoju rolnictwa (World Bank, 1997). W latach 1998-2006 przeprowadzono projekt rozwoju systemu zdrowotnego. Jego celem była poprawa efektywności w alokowaniu i wykorzystywaniu zasobów zdrowotnych oraz poprawa funkcjonowania systemu opieki zdrowotnej poprzez wzrost jakości, skuteczności i zasięgu (World Bank, 2006). W 2006 roku Japońska Agencja Współpracy Międzynarodowej (Japan International Cooperation Agency, JICA) podpisała umowę z rządem Indii na udzielenie preferencyjnej pożyczki na pierwszą fazę projektu rozwoju sektora le- śnictwa w stanie Orisa. W 2017 roku, celem realizacji drugiej fazy projektu, podpisano umowę na kolejną pożyczkę. Program ten powstał $\mathrm{w}$ odpowiedzi na problem degradacji lasów i źródeł utrzymania w leśnych okolicach (JICA, 2017). Ponadto, w 2007 roku JICA zaangażowała środki finansowe $\mathrm{w}$ projekt na poprawę warunków sanitarnych w regionie. Środki na drugą fazę tego projektu przekazano w 2016 roku. Pomoc miała objąć m.in. rozbudowę sieci kanalizacyjnych oraz systemów odwadniających w miastach stanu Orisa (JICA, 2016). W 2015 roku Orisa otrzymała środki od JICA na projekt poprawy systemu przesyłowego (JICA, 2015). W 2016 roku władze Orisy zwróciły się do Banku Światowego $z$ prośbą o wsparcie finansowe na projekt rozwoju edukacji wyższej (World Bank, 2017). Jest to tylko kilka przykładów pomocy rozwojowej, kierowanej do stanu Orisa.

\section{Metody}

W artykule zastosowano kilka metod badawczych. Jedną z nich jest analiza danych wtórnych. Wykorzystano literaturę w zakresie pomocy rozwojowej, historii gospodarczej Indii oraz roli tego państwa jako jednego ze wschodzących donatorów. Poddano również szczegółowej refleksji zdjęcia wykonane przez uczestników wyjazdów do Indii z ramienia Uniwersytetu Ekonomicznego w Poznaniu wykonane w lutym 2017 i 2018 roku. Fotografowane obrazy wykonano w kilku miejscowościach stanu Orisa. Kolejną metodą była obserwacja uczestnicząca przeprowadzona w lutym 2017 i 2018 roku wśród ludności plemiennej w dystrykcie Kandhamal oraz w miastach Bhubaneswar i Puri w stanie Orisa.

\section{Wyniki badania}

Analiza danych dotyczących wskaźników ubóstwa, struktury ludności oraz problemów, $z$ jakimi zmaga się indyjskie społeczeństwo, zwłaszcza w ubogim stanie Orisa, znalazła potwierdzenie $\mathrm{w}$ dokonanych obserwacjach, została również uwieczniona na fotografiach. 
Głównymi trudnościami, z którymi boryka się miejscowa ludność są: brak wody, energii elektrycznej, edukacji, a co za tym idzie umiejętności w wykorzystaniu dóbr naturalnych (Rothermund, 2010, ss. 171-183). Najuboższe okręgi $w$ regionie są zamieszkałe przez ludność plemienną oraz społeczeństwo z najniższych kast. Ich głównym źródłem utrzymania jest praca w rolnictwie (Sahoo, 2015, s. 4). $\mathrm{W}$ miastach zauważalny jest wysoki odsetek osób bezdomnych, w wielu miejscach można napotkać pokaźnych rozmiarów slumsy. Brak szkół sprawia, że dzieci przez większość dnia pozostają pozbawione opieki dorosłych. Przez utrudniony dostęp do edukacji, która umożliwiłaby polepszenie warunków życia w przyszłości dzięki pracy zawodowej, są one narażone na zjawisko dziedziczenia ubóstwa. Kolejnym problemem są nagminne porwania i gwałty dzieci czy przymuszanie ich do niewolniczej pracy lub prostytucji.

Brak dostępu do opieki medycznej, przy bardzo słabych warunkach sanitarnych, również jest ogromnym wyzwaniem dla mieszkańców, m.in. poprzez pojawianie się negatywnych efektów zewnętrznych. Takie warunki ułatwiają przenoszenie się chorób, stwarzają nawet zagrożenie epidemii. Wizyty lekarskie są płatne i niejednokrotnie wymagają pokonania wielu kilometrów. Liczba lekarzy jest także zbyt mała, aby obsłużyć taką liczbę pacjentów. Często najuboższe osoby opłacane są przez organizacje pozarządowe, które zajmują się zapewnieniem opieki medycznej w swoich placówkach. Przykładem jest szpital dla trędowatych zbudowany w Puri. Dyżury lekarskie odbywają się dwa razy w tygodniu. Za każdą wizytę lekarz otrzymuje 10000 INR (około 535 PLN). Od pacjenta pobiera się 5 INR. Pozostała kwota jest dofinansowywana ze środków organizacji. Placówka przyjmuje pacjentów nie tylko zamieszkujących wioskę trędowatych. Do szpitala przybywa też wiele osób z miasta i okolicznych wiosek.

Innym, negatywnym skutkiem braku edukacji jest marginalizacja osób chorych (na trąd lub zakażonych wirusem human immunodeficiency virus, HIV) oraz niepełnosprawnych fizycznie czy umysłowo. Osoby takie, traktowane jako przeklęte przez bóstwa czy też opętane przez demony, są wyrzucane ze swoich domów, wiosek, pozostawiane na ulicach. Wsparcie otrzymują jedynie poprzez działalność organizacji pozarządowych. Zakładane głównie przez misjonarzy-werbistów organizacje takie, jak Jana Vikas czy też Karunalaya Leprosy Care Centre, odpowiadają na bieżące potrzeby mieszkańców stanu Orisa. Poza wsparciem finansowym, żywnościowym oraz tworzeniem szeregu programów pomocowych dla najuboższych, misjonarze starają się także minimalizować wszechobecną przemoc, dyskryminację i brak poszanowania dla praw kobiet.

$\mathrm{Na}$ przeciw tym wszystkim czynnikom hamującym rozwój, wychodzą instytucje i państwa świadczące ODA. Wspomniane wcześniej projekty mają na celu zmniejszenie skali problemów. Jednak nakłady środków finansowych są zdecydowanie zbyt małe. Ponadto, prowadzone są zgodnie $z$ priorytetami politycznymi oraz strategicznymi donatorów (Sobotka, 2009, s. 164). Dokładne sprecyzowanie celów i narzędzi pomocy adekwatnej do potrzeb nie jest główną determinantą planowania pomocy. $Z$ uwagi na problem korupcji, istnieje również zagrożenie marnotrawstwa czy też niewłaściwego wydatkowania otrzymanych środków. Według Corruption Perceptions Index w 2017 roku Indie otrzymały 40 punktów na 100 możliwych, gdzie zero oznacza brak korupcji, a sto, bardzo skorumpowane państwo (Transparency International, 2018).

Przewaga projektowej formy nad programową osłabia natomiast skuteczność pomocy rozwojowej, gdyż jej efekty są krótkoterminowe. Stanowią doraźne działania, które nie rozwiązują problemów, tylko chwilowo je minimalizują. Zmiany, które powinna spowodować otrzymywana przez Indie pomoc rozwojowa, powinny doprowadzić do wewnętrznych reform, które usprawnią działanie państwa w problemowych, wymienionych wyżej obszarach. 


\section{Zakończenie}

Pomoc rozwojowa $z$ definicji jest środkiem wspierania rozwoju mniej rozwiniętych państw świata. Obecnie jednak, stale powiększa się grupa wschodzących donatorów. Należą do nich państwa zaliczane do beneficjentów ODA, które także świadczą pomoc rozwojową. Przypadek Indii pokazuje, że humanitarne motywy pomocy nie są główną determinantą jej udzielania. Przede wszystkim pomoc rozwojowa stanowi środek budowania relacji politycznych i ekonomicznych $z$ państwami, którym ta pomoc jest oferowana. W obliczu niedoborów, z jakimi zmagają się Indie, kluczowym wydaje się pytanie o to, co władcy polityczni tego państwa uznają za rozwój. Tempo wzrostu gospodarczego nie jest bowiem jednoznaczne ze zmniejszeniem poziomu ubóstwa czy poprawą jakości życia obywateli, czego przykładem może być sytuacja ekonomiczna, polityczna i społeczna mieszkańców stanu Orisa. Definicja pomocy rozwojowej i rozwoju zdaje się zacierać w tym przypadku i odbiegać od pierwotnego założenia, jakim jest dbanie o dobro człowieka. $Z$ pewnością zagadnienie to stanowi podstawę do dalszych badań i wprowadza potrzebę kolejnych obostrzeń dla świadczących pomoc rozwojową, aby minimalizować wszelkie rodzące się na tej płaszczyźnie nadużycia.

\section{Bibliografia}

Alesina, A., i Dollar D. (1998). Who gives foreign aid to whom and why? Journal of Economic Growth, 5(1). doi:10.1023/A:1009874203400.

CEBR. (2014). World economic league table 2015. Pobrane 10.04.2018 z https://cebr.com.

Encyklopedia PWN. (2018). Pobrane 10.04.2018 z https://encyklopedia.pwn.pl.

JICA. (2015). Signing of Japanese ODA loan agreement with India. Pobrane 10.04.2018 z https://www. jica.go.jp.

JICA. (2016). JICA extends ODA loan of 25,796 million Japanese Yen (approx. INR 1,535 crore) for Odisha Integrated Sanitation Improvement Project (Phase II). Pobrane 10.04.2018 z https://www. jica.go.jp.
JICA. (2017). JICA extends ODA loan of approximately INR 900 crores for Odisha forestry sector development project (Phase 2). Pobrane 10.04.2018 $z$ https://www.jica.go.jp.

Kopiński, D. (2011). Pomoc rozwojowa: teoria i polityka. Warszawa: Difin.

Nowik, M. (2014). The dynamics of development assistance in Asia: the case study of India. International Business and Global Economy, 33. doi:10 .4467/23539496IB.13.051.243.

OECD. (2018). Net ODA. Pobrane 10.04.2018 z https://data.oecd.

Rothermund, D. (2010). Indie: nowa azjatycka potęga. Warszawa: Dialog.

Sahoo, P. (2015). Dynamics of rural poverty in Odisha. MPRA Paper, 75520.

Słownik Języka Polskiego PWN. (2018). Pobrane 10.04.2018 z http://sjp.pwn.pl.

Sobotka, B. (2009). Efektywność pomocy rozwojowej. Warszawa: SGH.

Szulec, P. (2015). Indie: gospodarcza potega z wieloma stabościami. Pobrane 24.07.2015 z http://inwestycje.pl.

Transparency International. (2018). Corruption perceptions index 2017. Pobrane $10.04 .2018 \mathrm{z}$ https://www.transparency.org.

World Bank. (1997). India: Orissa agricultural development project. Pobrane 10.04.2018 z http:// documents.worldbank.org.

World Bank. (2006). India: Orissa health systems development project. Pobrane 10.04.2018 z http:// documents.worldbank.org.

World Bank. (2016). Odisha poverty, growth E inequality. Pobrane 10.04.2018 z http://documents. worldbank.org.

World Bank. (2017). Odisha higher education program for excellence and equity. Pobrane 10.04.2018 $z$ http://projects.worldbank.org.

\section{Informacje uzupełniające}

Wkład autorski: autor zaakceptował ostateczną wersję artykułu.

Źródła finansowania: artykuł został w całości sfinansowany ze źródeł Uniwersytetu Ekonomicznego w Poznaniu.

Uwagi: wyniki badania były zaprezentowane na VIII Ogólnopolskiej Konferencji Naukowej z cyklu Problemy gospodarki światowej (Torun, 20.04.2018). 
India in the global development assistance system

\section{Abstract}

Motivation: There is a lack regarding the assessment of the effectiveness of development assistance received and provided by India in the subject literature. The benefits of completing the existing research gap were the main motive for choosing the topic.

Aim: The aim of this article is to assess the development assistance in India as one of the emerging donors. Various aspects of development were taken into account, especially from the perspective of the poorest society in the country. Materials and methods: The analysis of the subject literature, secondary data analysis, participant observation and visual analysis were used.

Results: Analysis of literature review and conclusions from the observation leads to the reflection on the lack of the effectiveness and efficiency of the development assistance, both received and provided by India. In addition, the case of India suggests non-conformity between definition of development assistance as an instrument that generating growth in beneficiary countries but rather as a tool to create the political and economic relations which serves mainly donors.

Keywords: development assistance, India, emerging donors

JEL: 131; 019; N45 